University of Warwick institutional repository: http://go.warwick.ac.uk/wrap This paper is made available online in accordance with publisher policies. Please scroll down to view the document itself. Please refer to the repository record for this item and our policy information available from the repository home page for further information.

To see the final version of this paper please visit the publisher's website. Access to the published version may require a subscription.

Author(s): Ben Clift

Article Title: French Corporate Governance in the New Global Economy: Mechanisms of Change and Hybridisation within Models of Capitalism

Year of publication: 2007

Link to published version:

http://dx.doi.org/ 10.1111/j.1467-9248.2007.00655.x

Publisher statement: The definitive version is available at www.blackwell-synergy.com 


\title{
French corporate governance in the new global economy: mechanisms of change and hybridisation within models of capitalism ${ }^{\mathrm{i}}$
}

\author{
Ben Clift B.M.Clift@Warwick.ac.uk, Department of Politics and International Studies, \\ University of Warwick, http://www2.warwick.ac.uk/fac/soc/pais/staff/clift/:
}

\begin{abstract}
This article analyses the implications of the internationalisation of capital markets, and the influx of Anglo-Saxon institutional investors, for the French model of capitalism. Its central contention is that the global convergence thesis misrepresents contemporary evolutions because it pays insufficient attention to mechanisms of change within models of capitalism. Secondly, framing analysis in terms of hybridisation and fragmentation of national models, rather than convergence, offers greater explanatory purchase over the French model, constitutes a more accurate characterisation, and helps avoid the ‘convergence or persistence' impasse within models of capitalism analysis. In exploring French corporate governance, it emphasises the importance of specifying the role of institutional mechanisms as transmission belts of change as a precursor to an assessment of how far shifts in international political economic context bring about changes within French capitalism. Focusing on financial market regulation regime, new legislation in corporate governance and company law, and the market for corporate control as three key potential mechanisms of change, it finds that pre-existing norms and structures endure, mediating the nature of a national political economy's articulation with the international
\end{abstract}


context. Hybridisation, and recombination of capitalist institutions drawn from different models, provide a far more persuasive account than convergence.

\footnotetext{
i The author would like to thank Michel Goyer, and three anonymous referees, for helpful and insightful comments on an earlier version of this article.
}

\section{French corporate governance in the new global economy: mechanisms of change and hybridisation within models of capitalism}

There have been remarkable increases in the degree of enmeshment and interconnectedness of capital markets in a number of advanced post-industrial countries in recent decades, characterised by McGrew as the 'financial deepening' of globalisation, arising 'out of the interaction between greater 'financialisation' of national economies and the scale of global financial activity' (2005: 214). In the French case, the resultant internationalisation of capitalism has seen dramatic rises in transborder mergers and acquisitions, French companies listing overseas, French portfolio investment in foreign stock markets, and foreign ownership of stock listed on the Paris bourse. This has enmeshed French firms in a set of global financial markets and networks. The protective barriers behind which French capitalism restructured in the 1980s have become much more porous today, with major implications for the French political economy's point of insertion into and articulation with its international context.

This exploration of the implications of these changes for the political economy of French corporate governance is informed by combined insights of recent developments in the international political economy (IPE) and comparative political economy literatures. 
There is increasing recognition that the complexity of economic globalisation generates 'patterns of both economic convergence and divergence' not captured by 'neoclassical or linear models of economic globalisation which equate it solely with global economic convergence' (McGrew 2005: 220). Anticipation that convergence will occur and is needed to 'prove' the existence of globalisation is flawed, rooted in a textbook neoclassical economic model, and the theoretically threadbare 'logic of no alternative' argument, both projected unhelpfully onto the global political economy. Rather, how the process of globalisation really 'plays out' is 'highly uneven such that it is associated with both economic convergence and divergence, as different economies/subregions/sectors are differentially integrated into this globalizing world economic order' (McGrew 2005: 221). In this light, diversity of responses to globalisation, and the particularities of how it is mediated by 'domestic' institutions and politics, are all part of the 'variable geometry' (Castells 2000) of globalisation.

Such thinking prepares the ground for cross-fertilisation between IPE and comparative political economy analysis. Many comparative political economy scholars have become increasingly frustrated with the 'are we witnessing either convergence or persistence' framing of the debate about the evolution of models of capitalism. Thus, in this case, either the French political economy is preserved in aspic, or the French political economy is continually evolving in a process of convergence. Such a cul de sac struggles to account for the co-existence of dramatic changes (many along similar lines in different cases) and enduring highly significant particularities. 
A further problem with the convergence account is that use of ideal types leads to a stylised, caricatured version of the 'Anglo-Saxon' or liberal market economy (LME) model becoming the yardstick by which convergence is judged. Yet the US political economy, for example, often fails to conform to the ideal-type supposedly so closely modelled upon it (see Crouch 2005: 441-2). Indeed, this is particularly true of corporate governance. Large US companies developed a range of anti-takeover devices ("shark repellents”) in the wake of the 1980s takeover boom, notably through state law legislation and favourable state court decisions (Monks \& Minow 2004: 42, 110-120, 232-239). This created impediments to the market for corporate control, generating a disparity between US corporate governance and the LME ideal-type.

A number of ways out of the 'convergence or persistence' impasse have been suggested. Hay, for example, frames his analysis in terms of 'common trajectories, variable paces, divergent outcomes' (Hay 2004), whilst others have characterised evolutions in terms of ‘hybridisation’ (Perraton \& Clift, 2004: 258; Lütz 2004: 189). Hybridisation is helpful because it captures the qualitative nature of change, doing less violence to the facts than a rather too loosely and liberally applied notion of convergence.

Hybridisation itself, however, can be subject to different interpretations. Lütz's sophisticated recasting of the convergence thesis talks of 'convergence within national diversity’ (2004: 171) and ‘cross-national patterns of convergence and diversity’ (2004: 184). This nuanced conception of convergence recognises that 'cross national diversity also characterises the timing of regulatory efforts, and the extent of institutional change' 
(2004: 186), and how 'weight shifting among actors ... takes place within institutional frameworks of regulation that are still diverse across countries' (2004: 184). Thus 'domestic responses to globalisation' involve a mixture of both 'convergence' and 'persistence' (2004: 189). Yet this raises the spectre of 'conceptual stretching'. If all these caveats are admitted, are we really still talking about convergence? Moreover, it is difficult to see how any evidence could be interpreted as contrary to this convergence thesis.

The elision within this 'hybridisation as convergence' argument is to interpret all change (even non-convergent change) as evidence of convergence. Logically, what is being converged towards in this account is something rather different from the standard 'AngloSaxon’ LME ideal-type (Hall \& Soskice 2001: 27-33), and to this extent it represents a considerable improvement on the simple convergence thesis. Nevertheless, the very term convergence conveys the sense of a telos at work reducing ever further the difference across cases.

Crouch offers further potential to escape the 'persistence versus convergence' impasse. Crouch criticises the varieties of capitalism approach for being 'fixed over time,' making 'no provision for changes in characteristics' (2005: 444). In analysing what he calls variously 'capitalist diversity', and 'the diversity of economic institutions', Crouch argues that 'empirical cases should be studied, not to determine which (singular) of a number of theoretical types they should each be allocated, but to determine which (plural) of these forms are to be found within them, in roughly what proportions, and with what 
change over time' (2005: 440). The resultant 'recombinant capitalism' approach to models of capitalism analysis involves 'deconstructing into constituent elements and then being ready to recombine into new shapes the aggregated forms' (2005: 440). Through this lens, a more differentiated political economy of capitalism can be analysed, accounting for change without reference to convergence.

This article adopts such an approach, and illustrates its relevance through a focus on specific mechanisms of change within French capitalism. These mechanisms of change do not receive the attention they deserve within much comparative institutional political economy analysis. Indeed, Campbell argues that 'institutionalists rely on causal concepts but often without specifying the underlying mechanisms or processes by which change occurs ... vague concepts end up carrying much of the argument when, in fact, mechanisms should be doing the work' (2004: 5). The mediation of McGrew's 'financial deepening' of globalisation through these mechanisms of change explains why hybridisation, and 'recombination' of different capitalist forms are the most likely outcomes, rather than convergence, or 'dual convergence' on the liberal and co-ordinated varieties of capitalism (Hall and Soskice 2001; for a critique see Hay 2004: 232-8).

The focus here on French corporate governance identifies the key mechanisms of restructuring, and assesses the degree of change within French capitalism. Corporate governance involves a key 'nexus of institutions' (Cioffi 2000: 574) through which governments, state actors and stakeholders organise and regulate corporate and economic activity. Its impact on actors' behaviour, norms and incentive structures shapes how 
capitalism works in any given setting. Key mechanisms of change within corporate governance, often associated with restructuring along the lines of Anglo-Saxon capitalism, include the market for corporate control, transparent accounting, and shareholder value norms.

This analysis of the role of institutional mechanisms of change within French corporate governance suggests a rethinking of 'institutional complementarity', normally seen as the cement which ensures persistence of Varieties of Capitalism (Hall \& Soskice 2001: 1721). Here, the focus on mechanisms of change illustrates how institutional complementarity is more helpfully deployed in explaining the differential effects of similar kinds of changes within capitalisms. The impact of a single institution in a given framework is mediated by the presence of other institutions, thus the same institution will produce different consequences across different institutional frameworks. For example, the piecemeal introduction of shareholder-oriented reforms in France detailed below charts their interaction with domestic institutions such as the intérêt social of the company. This produces different consequences than pro-shareholder mechanisms combined with principles of shareholder value, as in the UK. The resultant hybridised mix of French and 'Anglo-Saxon' corporate law norms represents an instance of what Campbell calls 'translation', or 'the combination of locally available principles and practices with new ones originating elsewhere' (2004: 65).

Hybridisation and fragmentation of national models (Perraton \& Clift 2004: 258), and ‘recombination’ of different capitalist forms (Crouch 2005) provide far more persuasive 
narratives than the convergence of capitalisms thesis. The reason is rooted in the mechanisms of change, and how they shape the impacts of international changes on the internal dynamics of capitalism. The first section establishes the context of the recent restructuring of French capitalism, and key evolutions in French capital markets. The remainder of the article identifies the key potential mechanisms of change. Analysis focuses on the financial market regulation regime, specific government regulatory policies in the field of corporate governance and company law, and the market for corporate control. Finally, the conclusion draws out the implications of these findings for comparative and international political economy analysis.

\section{The Restructuring of Financial Markets and Ownership within French Capitalism}

To a degree, the restructuring of French capitalism in the 1980s and early 1990s was carried out behind barriers that protected large firms from the demands of portfolio investors. These included the role of the state as both owner and orchestrator of 'managed capitalism', cross-shareholding, and interlocking board directorships. For example, the privatisation process between 1986-1988 was managed by finance minister Balladur to deliberately reinforce France’s protected ‘financial network economy’ (Schmidt 1996: 369-392). Both Morin (1998; 2000) and Goyer (2003a \& b) note significant shifts within the 'financial networks' that hitherto articulated the core of the French economic model, suggesting that those barriers are considerably more porous today. The reconstructing of noyaux durs (or 'hard cores' of interlocked investors) and creation of interlinking networks to articulate the French model of capitalism was, it seems, a transitional phase. 
One marked feature of the restructuring process is the internationalisation of ownership and shareholding patterns in France. This departed from post-war norms, when foreign investment was discouraged, and even opposed by the French state (Michalet, 1997: 31920). From the mid-1990s, further privatisation became an important catalyst in the unravelling of the noyaux durs.

The noyaux durs, previously maintained by merger and acquisition (M \& A) strategies that sustained cross-shareholding, began to unravel in the late 1990s. The extremely healthy profit margins of French business from the mid-1980s onwards tended to be creamed off as profit rather than re-invested within French firms (Lordon 2001). Despite such healthy profit margins, a 'conglomerate discount' penalised French firms for the (perceivedly less efficient) organisational form, leading Goyer to argue that these large French firms were substantially under-capitalised in the mid-1990s (2003b). This opportunity to extract the surplus profits associated with a 'correction' in firms' market value meant that, just as large equity stakes in these firms were becoming available through privatisation, and the liberalisation of French capital markets, there were strong incentives to invest in these companies. The equity stake of hard-core shareholder groups fell significantly, and the equity holding of foreign investors, notably Anglo-Saxon institutional investors, grew substantially.

The expansion in foreign holdings on the French stock exchange is remarkable. Between 1985 and 1997, foreign owners increased their share of stock exchange capitalisation from 10 per cent to 35 per cent (compared to 9 per cent in Britain, and 6 per cent in the 
US) (Morin, 2000: 42). By November 2000, of CAC 40 (top 40 French firms), the average foreign equity holding was over 40 per cent - a record among world's leading industrial nations (Maclean 2002: Table 7.7).

Anglo-Saxon institutional investors' strategic priorities were defence of 'core business', breaking up of conglomerates, externalising 'non-strategic' activities, and share buy backs as a means of increasing shareholder value (Morin, 1998, 21-48; 2000: 48-9). These, in combination with acquiring core business (notably research and development) overseas, were seen as the best means to raise the market capitalisation of the firms in which they had recently acquired stakes (Goyer 2003b). Rising market capitalisation of these large French firms in the late 1990s facilitated the process of M \& A integral to restructuring because these transactions were increasingly carried out using not cash but equity swaps (Macaire \& Rehfeldt 2001). M \& A saw a very sharp increase, with 1999 and 2000 showing particularly spectacular levels of French firm acquisition of foreign companies (UNCTAD 2003; Commissariat du Plan 2004: 27-33). This was the product of the partial unravelling of the noyaux durs. Selling cross-shareholdings reassured foreign investors that French firms were responsive to shareholder concerns (Morin 1998; 2000: 38-42). This M \& A activity focused on international concentration on core strategic activity, and differs from earlier noyau dur reinforcing strategies. This is particularly true of firms where US pension funds invested heavily, suggesting that the shareholder value dominant strategic paradigm is an important driver behind the contemporary restructuring (Kechidi 2003: tables 4 \& 5). 
AXA-UAP's shareholding links with many key players across the various hard cores in the mid-to-late 1990s could have given AXA a pivotal role in orchestrating the financial nexus of France's political economy, yet it chose to relinquish significant stakes in a range of major firms, including Crédit National, Schneider and Suez, and retained only those holdings it saw as essential to its core business. Such moves from the protective logic of unrelated cross-shareholdings within France's 'financial network economy' (Morin 2000: 37), and towards Anglo-Saxon shareholder value norms began a trend since emulated by other significant players within the noyaux durs, notably with the AllianzAGF buy-out in 1997 (Morin 1998, 2000: 41; Goyer 2003; O’Sullivan, 2003). The degree of erosion of noyaux durs is considerable but not complete. ${ }^{2}$ Loriaux notes that 'the hard core now represents less than 30 per cent of the capital for half of France's blue chip, CAC 40 enterprises, less than 20 per cent for fifteen of the forty, and less than 10 per cent for five of the forty' (2003: 116; see also Morin 2000: 39).

A key mechanism of influence of Anglo-Saxon corporate governance is dispersal of ownership, yet the distribution of share ownership remains much more concentrated in France than is the case in either UK or US (O'Sullivan 2003: 42; Schmidt 2003: 539). Reinforcing the 'protected capitalism' image of French large firm ownership and control, and deviating from Anglo-Saxon norms, the level of family ownership of major French firms is the highest in Europe. In terms of both ownership of capital and voting rights, 15 families control nearly 35 per cent of the capitalisation of the French stock market - with five families controlling 22 per cent of stock market capitalisation, and the top ten families 29 per cent. The equivalent levels for the UK are 4.1 per cent and 5.8 per cent 
respectively (LeMaitre 2003). Significantly, the conglomerate restructuring noted above has not taken place evenly across all sectors or firms. In particular, large family-owned firms have in many cases not followed these prevalent trends (Goyer 2003b). Family dominates ownership and firm structures in approximately 50 of the top 100, including such household names as Michelin, Leclerc, and Peugeot (MacLean 2002: 211-12; Schmidt 2003: 540-1). More than half of the top 250 French firms are predominantly family owned (Lauer 2002).

\section{Anglo-Saxon institutional investors - Trojan horses or sleeping partners?}

The proportion of foreign equity holdings on the Paris bourse has acquired totemic status within the French political economy debate as indicating a paradigm shift. The power of UK/US institutional investors to transform 'domestic' corporate governance practises is widely accepted (Morin 1998; 2000), and some see US institutional investors as Trojan horses of Anglo-Saxon capitalism (Desportes \& Mauduit 1999). The degree of change needs to be carefully gauged across different aspects of corporate governance. The causal mechanisms by which the Anglo-Saxon influx brings about transformation needs to be specified, and the implications of these changes for the French model of capitalism need to be set out with precision.

Whilst it is straightforward to establish the shareholder-value oriented preferences of Anglo-Saxon institutional investors, it is much trickier to establish to what extent these preferences prevail. It is difficult to causally link this ownership of equity with any direct 
impact on how firms behave strategically. Morin sees Anglo-Saxon institutional investors as active shareholders, monitoring management methods and decisions and making their voices heard (1998), yet he also points to the interaction of Anglo-Saxon norms with enduring French institutions, including the French social model (2000: 47-8). Kechidi insists that new ownership patterns involve 'influencing behaviour' of firms, not 'controlling' them (2003). Aglietta and Rebérioux, (2005: 62), building on the work of Boutillier et al (2002) note that the levels of holdings in any one company are small normally between two and three per cent, thus Anglo-Saxon institutional investors 'have taken their place in the 'float' of company equity', but that they remain 'outside the structures and controlling interest', they 'the ability and desire of these investors to impose their views in a foreign context is doubtful'.

This chimes with other work on the inter-relationship between funds and French firms, which points to the weakness of the transmission belts translating Anglo-Saxon corporate governance preferences into practice. The dominant trend is an information-cost effective 'passive monitoring' rather than shareholder activism. Funds remain 'external' actors, and minority shareholders within. Foreign institutional investment funds do not exploit opportunities to influence management decisions directly. With the exception of the (few) speculative funds managed by 'raiders', fund managers do not seek direct influence in 'operational' firm decision-making (Plihon, Ponssard and Zarlowski 2002: 163). This suggests a limited impact of the influx of Anglo-Saxon institutional investors, and helps account for the diversity of responses, within French corporate governance, to financial globalisation. 


\section{Mechanisms of change ... the Transformation of French Corporate Governance?}

If the funds tend not to rely on direct influence, then what mechanisms might bring about the mooted Anglo-Saxon transformations within French capitalism? How, for example, have the incentives of the key French corporate actors changed? The following section isolates three key mechanisms of change within French corporate governance. Attention focuses first on the regulatory context of French financial markets and its recent evolution. Secondly, a wide-ranging legislative reform of corporate governance, the Nouvelles Régulations Economiques (NRE), is considered, before analysing the market for corporate control in France.

In this way, the mechanisms by which changing ownership patterns of French capitalism might bring about a reshaping of the financial architecture of French corporate governance, and a transformation of the logic of French corporate capitalism, are identified. It is then possible to examine the degree to which the changes mooted above have indeed taken place. Analysis proceeds in the spirit of Crouch's 'recombinant capitalism' approach, which identifies the need to 'deconstruct the wholes that contemporary institutionalism takes for granted and discover their constituent elements elements which are able to survive in combinations other than those thus identified' (2005: 439-440).

\section{Mechanism 1: French financial market regulation}


Financial market regulation is one key element (alongside company law and labour law) within the 'nexus of institutions' (Cioffi 2000: 574) which constitute the corporate governance regime. The institutional and regulatory context of French financial markets has evolved significantly in recent years, partly in response to the internationalisation of French capital markets. The Commission des Opérations de Bourse (COB) was initially modelled on the US Securities and Exchange Commission (SEC) in 1967. It has played a key role in the development of French financial markets. Liberalising 're-regulatory' reforms in the 1980s transformed French financial markets along Anglo-Saxon lines. These included creating the French futures market, the Second Marché of unlisted securities, and decompartmentalising and freeing up securities, futures and foreign exchange markets (Loriaux 1991: 214-225; Cerny 1989: 178-83). These reforms involved a substantial extension of the regulatory oversight powers of the COB. The COB has recently been further empowered through the NRE (Aglietta \& Rebérioux 2005: 61), and its role in ensuring transparency of information passed to shareholders has expanded. Furthermore, the COB has increased the transparency requirements it must itself meet (Frison-Roche 2002: 79, 82-90). US-style centralisation of market authorities has also been emulated, with the merging of the $\mathrm{COB}$ and the Financial Markets Council into the Autorité des Marché Financiers (AMF) in 2003 (Aglietta \& Rebérioux 2005: 61).

Although much comparative capitalisms literature sees institutional complementarities as shoring up persistence and dual convergence (Hall \& Soskice 2001: 14-21), Goyer rightly points out that the constraining effect of 'institutional complementarities' should not be 
overstated (2003b: 202-4). Specific aspects of French corporate governance have changed dramatically in recent years, despite the fact that they hitherto dovetailed with a range of other institutional features of French capitalism. Such 'institutional complementarities' did not, in this instance, prevent evolution. In financial market regulation, independent regulatory authorities based on Anglo-Saxon self-regulatory models have been established and recognised despite their paucity of fit with traditional French hierarchical authority structures and legal norms detailed below (Magnier 2002: $68)$.

Frison-Roche regards the influence of the French financial market authorities on management as analogous to that of foreign investment funds, encouraging focus upon rates of return, 'shareholder value' oriented management decisions, and transparency (Frison-Roche 2002: 79, 82-90). Thus those identifying convergence towards AngloSaxon shareholder value norms find succour in the changes to French financial market regulation (Cioffi 2000). As Aglietta and Rebérioux (scholars sharply critical of the convergence thesis) note of French financial market law, 'signs of convergence are therefore evident: the transparency of information given to shareholders as a whole has progressed greatly, while the role of market authorities continues to grow' (2005: 61).

Yet before extrapolating from these changes in the French financial regulatory framework, one should ask what impact they have had on the behaviour, organisation, and market operations of large French firms? In the crucial area of transparency, where much new regulatory activity has been directed, the evidence presented below suggests 
only limited change. Despite two decades of institutional and regulatory evolution towards Anglo-Saxon norms, practice continues to diverge.

French firms have been reluctant to institute a thorough-going shift to greater transparency. Some of France's largest firms still resist the push towards transparency and accountability (Maclean 2002: 210), baulking at introducing international accounting standards, or more stringent criteria for awarding options (O’Sullivan 2003: 41), and neglecting to monitor executive compensation, presenting an open door to financial scandal (Goyer 2003a). Of the 100 largest French firms quoted on the Paris bourse, only 35 had adopted international accounting standards in 1997, and this number had only risen to 38 by 2000 (Goyer 2003b: 188-9, 196). This should all be situated in the context of the historic opacity of the French system of corporate governance (Maclean 2002; O’Sullivan 2003). The fact that an historically non-transparent regime has undergone only minor change despite the best efforts of an empowered regulatory authority suggests the very opposite of the 'functional convergence' comparative political economy thesis (Gilson 2003; Coffee 1999). This argues that an absence of formal institutional change is deceptive, because actual practice within capitalism maybe converging on Anglo-Saxon norms despite the absence of institutional changes. Here, it seems, formal institutional change has been achieved, but it has not succeeded in changing firm practices. What has emerged is a 'complex amalgam,' a 'recombination' (Crouch 2005) of pre-existing (opaque) French corporate norms with new financial market authorities prioritising transparency in a configuration characterised by 'a degree of complication and apparent incoherence’ (Crouch 2005: 453). 


\section{Mechanism 2: The Nouvelles Régulations Economiques}

Culpepper claims that the French state has been 'excised' from finance and corporate governance (2004: 14-15). The bolstered role of the financial regulatory authorities detailed above suggests this view is erroneous. As Vogel (1996: 1-5, 16-24), and before that Polanyi (2001 [1944]: 71, 79-80, 146-7, 258) have demonstrated, freer markets paradoxically involve more rules. The 'liberalisation' and internationalisation of French financial markets have led to their re-regulation (Vogel 1996: 237-243), and the centralisation and empowerment of financial market authorities. This is consistent with Levy's 'the state also rises' thesis, with new state activities being developed in an age of globalisation (2006). Thus Culpepper's assertion does not accurately characterise modes of contemporary state co-ordination. Moreover, it fails to capture how the French state continues to attempt to pursue a quasi-dirigiste strategy, by novel means, and with less direct intervention (Clift 2001; Loriaux 2003; Maclean 2002; Schmidt 2003).

The French state's role as quasi-dirigiste actor in the process of the re-regulation of French corporate governance and financial markets was distilled into the Nouvelles Régulations Economiques (NRE) in May 2001. These began life in the context of Socialist Prime Minister Jospin's aspirations to manage the economic impacts of globalisation more effectively. Specifically, after the September 1999 Affaire Michelin, involving 7,500 layoffs, despite profits for the first half of 1999 being up 17 per cent (Forrester 2000: 113-4), Jospin sought to limit 'abusive layoffs' (Jospin 1999) oriented 
solely towards increasing return on equity. This initial impetus was added to, arguably hijacked, by Treasury officials seeking to transform the French legislative environment in relation to competition law and mergers and acquisitions, as well as corporate governance (Tiberghien 2004: 19-20).

In addition to empowerment of state actors in the re-regulation of French financial markets, there has also been a partial judicialisation of French corporate governance. This trend has seen judges, rather than state actors, empowered in certain important respects. The resultant complex amalgam involves increased judicial activism co-existing with state activism, some of it novel, some more familiar. The key point here is that the mechanism of change, French company law, pushes evolution in a peculiar direction.

Elements of the NRE are consistent with the Anglo-Saxon evolution in French financial market regulation, especially the way the role of law is conceived. Frison-Roche notes how the NRE distributes rights 'to contest judicially the decisions of managers' (2002: 81). These rights of litigation apply not just to shareholders, but to all stakeholders. Furthermore, all company and related office holders can be tackled, including works councils and regulatory authorities. Magnier (2002: 67-72) discerns a general trend in the role of law within French corporate governance into which the NRE can be situated. The traditional interventionist, directive and regulatory instincts of the French state in relation to the private sector have been resisted. Earlier in the 1990s, this was illustrated in the Viénot reports on corporate governance, written under the aegis of the French Patronat, and characterised by Magnier as 'a mode of regulation without any state intervention' 
(2002: 68). The model being emulated, involving an appeal to the spirit of responsibility (accountability) of managers, but containing no coercive element, draws inspiration from the US Principles of corporate governance developed by American law institute and the American Bar Association (Magnier 2002: 68).

In this new context, it is increasingly judges, rather than state actors, who exercise influence over firm managers. Whereas traditionally, French law frames the activities of firm office-holders with procedures which, a priori, constrain their actions, in this US tradition, concrete, substantial controls are more important than procedures, and $a$ posteriori judgements upon managers' decisions play a key role. This approach is unusual in the French context, where law is constructed around the abstract notion of the general interest, secured and protected through the state’s hierarchical superiority.

Self-regulation of corporate governance according to professional norms (set out in the Viénot and Bouton reports) reinforces the need for judicial control, given the possibility of litigation by economic actors. Corporate governance norms thus play a preventative role, avoiding litigation arising. This situation calls into question judicial power, and evidence suggests an increasing power of judges within corporate governance, and more instances of judicial activism (Alcouffe 2000: 138 \& 140; Magnier 2002: 69; Aglietta \& Rebérioux 2005: 61). The changes in regulation raise questions about the boundaries between the public and the private, treading novel territory in terms of French regulatory and legal traditions. In their wake has come a more litigious corporate culture, empowering judges to evaluate a posteriori executive decision-making. To the extent that 
this new understanding of the role of law pervades, this represents an Anglo-Saxon shift. As Magnier puts it, this creates conditions potentially conducive to the 'judicialisation' of company law, contemporaneous to the ‘financialisation’ of French capitalism (2002: 70). Frison-Roche talks of an attempted 'hostile takeover' of French company law (2002: 79).

Within a context of wider corporate governance debates, La Porta et al (1998) see the quality of law protecting minority shareholders as the crucial determinant of the degree of dispersion of share ownership, the nature of equity markets, and the broader corporate governance regime. In this light, moving away from 'roman' law towards Anglo-Saxon common law could be of cardinal importance, representing a turning point on the road to convergence. Yet how effectively can these changes graft US legal norms onto French company law? National legal systems are not particularly amenable to convergence pressures. The idea of self-regulation according to professional codes, and the reliance on litigation between conflicting interests, has been only partially inculcated within French law and French capitalism. Most obviously, it sits uneasily with statutes and legislation that still fastidiously organise the internal relations of firms (Magnier 2002: 68).

The most significant illustration that this import cannot be interpreted as convergence is the importance, within French judges' deliberations, of the notion of intérêt social (social interest) of the firm. As the first Viénot report notes, it simply does not exist in AngloSaxon law, yet it plays a key role in French company law; 
In Anglo-Saxon countries the emphasis is for the most part placed on the objective of maximising share values, whilst on the European continent and France in particular the emphasis is placed more on the human assets and resources of the company (1995: 935)

It defines the social interest of the company as;

the greater interest of the body itself ... the company considered as an autonomous economic agent pursuing its own ends, distinct notably from those of its shareholders, employees, creditors (including tax authorities), suppliers and customers, but which correspond to their common general interest, which is to ensure the prosperity of the company (1995: 8)

As if to demonstrate how far removed from the shareholder value paradigm intérêt social can be, Alcouffe notes that it is partially derived from the encyclicals of the Catholic Church, rooted in the ideas of Thomas Aquinas. Regarding the aim of the company, these stipulate that it

is not merely the acquisition of profit but is the very existence of the company as a community of people who in their different ways search to satisfy their fundamental needs and who constitute a group peculiar to the service of the community as a whole (quoted in Alcouffe 2000; 134-5). 
Increasing judicial activism involves more judgements in relation to this intérêt social of the company as a distinct entity (Alcouffe 2000: 133-135), thus much hinges on its interpretation. In the affaire André, ${ }^{3}$ a high profile example where judges were called upon to adjudicate between management and two Anglo-Saxon institutional investors in a dispute which hinged on the definition of intérêt social, the judges found in favour of the management (Magnier 2002: 70-71). Interpretations of the intérêt social are contested within French corporate governance, yet all concur that it does not equate to shareholder interest (Alcouffe 2000; Frison-Roche 2002: 81).

The notion of intérêt social also interacts with long-standing traditions of Président Directeur Général (PDG) autonomy within French firms. This has changed little, with the exceptional PDG autonomy being retained as French capitalism has restructured. ${ }^{4}$ To give one salient example, intérêt social interacts with impediments to the market for corporate control (see below). The retention of privileged shares and unequal voting rights can be justified in the 'common interest of the company members' (Alcouffe 2000: 130), as distinct from the shareholder interest. It is often interpreted as through management activity, 'via powers and rights devolved to the heads of companies, the managers and administrators' (Alcouffe 2000: 135), that intérêt social is expressed. Thus intérêt social can in practice be used by management to enhance their very considerable autonomy.

Another important corollary of the intérêt social of the company is that it incorporates a wider range of actors than only shareholders or managers. Here Prime Minister Jospin 
had laid out in 1999 his desire to improve the consultation and information procedures with regard to salaried employees (Jospin 1999), and these were realised in the NRE. This highlights counter-tendencies within the NRE, and tells against interpreting the episode as convergence on Anglo-Saxon norms. In terms of stakeholder 'versus' shareholder conceptions of and approaches to corporate governance, the NRE is conspicuously 'stakeholder' oriented. The company in France is seen as something other than the property only of the shareholders, hence the right, stipulated in Article 99 of the NRE (Journal Officiel 2001: 7793), of representatives of the comité d'entreprise (works council) to attend shareholder assemblées générales, and receive the same information to which shareholders are entitled. The NRE gives workers the same rights of access to judges which shareholders currently enjoy (Plihon 2003: 50), and diversifies the sets of interests that executives must take into account along stakeholder lines, conferring on employees the right to express a defence of their interests in firm decisions (Frison-Roche 2002: 77-91). All this, of course, points in the opposite direction to the shareholder value model.

The conception of workers' interests underpinning this stakeholder approach construes them as analogous to shareholders' interests (see Jospin 1999). This is a paradoxical shift, given potentially antagonistic interests of shareholders and workers (Frison-Roche 2002: 86), which NRE provisions relating to layoffs and plans sociaux (redundancy plans) are likely to bring to the fore. In the French case, the discordant nature of shareholder and worker interests is reinforced by the fact that workers lack sufficient power within the firm to exploit any greater transparency and disclosure to their advantage. This reduces 
the likelihood of a pro-transparency shareholder-worker coalition similar to that detected in Germany (Jackson Hoepner \& Kurdelbusch 2005: 112-114). Furthermore, intérêt social, whilst preventing exclusively shareholder-oriented strategies, has not been deployed to enhance the status of workers within firms. Therefore there is little prospect of the worker empowerment (Goyer \& Hancké 2005: 190-194).

The shareholder AGMs, which worker representatives have a right to attend, are not the sites of the crucial decisions, for example, relating to redundancy plans, restructuring or wage policies. These decisions take place amongst senior management, where workers have no rights of access. Even where they do have a say, the best workers representatives can realistically hope to achieve is a delaying of the decision process (Montagne, Pernot and Sauviat, 2002: 3). As Goyer \& Hancké put it (2005: 189) '[w]hile French workers and their representatives have strong information rights, they have no formal veto rights'. Thus the attempt to specify a role for a wider range of stakeholders within the NRE does not necessarily translate into their empowerment.

Overall, labour has not been empowered within French corporate governance, but given the ideologically fragmented and confrontational history of French industrial relations (Milner 1995: 229), this is best interpreted as persistence, rather than convergence. Organised labour's limited power and influence in the contemporary French model is not 'brought about' by globalisation, rather, the latter constitutes a new context within which the enduring weakness of French labour manifests itself. 
The UK influenced 'good' corporate governance agenda (OECD 1999; 2004) demands the separation of the position of PDG into two discrete posts. The failure of the US model, where three quarters of large company bosses combine the roles of chairman of the board and CEO (Monks \& Minow 2004: 208), to live up to its Anglo-Saxon ideal type should be noted here. The NRE allows for such a split to be introduced into French firms (Journal Officiel 2001: 7794), but it does not tackle the issue of the respective roles of each, nor indeed the role of the board in the changed constitutional context (Magnier 2002: 73). The post itself has not, in most cases, been split into two, and the all-powerful PDG, who is both chair of the board and CEO remains the norm. The NRE explicitly conveys in Article 107 on the PDG a free reign to act 'the most extensive and wideranging powers ${ }^{5}$ (Journal Officiel 2001: 7794) in all areas except those where the law specifies a role for shareholder assemblies, or the board. The presumption, therefore, remains the widest freedom to act for the PDG. As Alcouffe notes 'such is the power of the PDG that it is considered "bad manners" for the board to take a vote on a decision, as it would show that the PDG had lost the confidence of the board' (2000: 129).

Traditionally, French law made it difficult for shareholders to vote, requiring voting intentions to be registered seven days in advance (Frison-Roche 2002). The NRE reduces the transaction costs involved in voting. Chapter 5 sets out the shareholders' rights, facilitating the participation of minority shareholders in shareholder meetings through electronic voting and video-conferencing, and significantly lowers the threshold required to ask written questions of the PDG (down from a 10 per cent to a 5 per cent holding). If no response is forthcoming, the law provides for experts to be appointed to report on the 
firm's operations (Journal Officiel 2001: 7798). According to Plihon, the NRE 'can be considered as a weakening of the power of managers in favour of shareholders' (2003: 49).

In the important area of transparency, the NRE substantially bolstered disclosure requirements for remuneration of all executive office holders (Art. 116), challenging the historic opacity of French corporate governance in general, and executive remuneration in particular. ${ }^{6}$ Although there remains some ambiguity as to what counts as 'remuneration' (Magnier 2002: 73), this increased disclosure is politically significant, given public disquiet at the introduction of 'stock options' during the controversial restructuring of the French food producing multi-national Danone in 2001. The rationale behind the layoffs was not a lack of profitability of the plant, but rather that financial market performance had not been sufficiently good to deliver stock option bonuses for executives (Mottis and Ponssard 2002: 140). This was widely interpreted as a dangerous portent of American-style capitalisme sauvage arriving on French soil.

However, despite NRE reforms, questions remain surrounding the transparency, the level, and the nature of executive remuneration (Jeffers \& Magnier 2002: 61-3). This, combined with the uneven distribution of new transparency-oriented corporate governance institutions and processes (Goyer 2003a: 6; O’Sullivan 2003: 41), indicate the problems of extrapolating from this dramatic example. The ability of these executive incentivising oriented changes to transform corporate behaviour may be more limited than the case of Danone suggests. There remains widespread resistance amongst some of France's largest 
firms to the push towards transparency and accountability (Goyer 2003b 194-7; O’Sullivan 2003: 58). Furthermore, the public outcry at the Danone saga demonstrated that the shareholder value paradigm has not taken root within French society, and popular capitalism is still not that popular (O’Sullivan 2003: 42; Hancké 2002 51-5).

Thus overall the NRE increases transparency requirements, and seeks to limit to management autonomy. Yet it also diversifies the sets of interests that executives must take into account along stakeholder lines. The NRE conceives of the role of law in a distinctly 'Anglo-Saxon' manner. Yet the content of French company law, and the enduring central importance of the concept of intérêt social of the company, indicates ongoing divergence from the 'shareholder value' paradigm. Crouch's 'recombinant institutions’ approach helps explain this complex configuration, with elements of more than one model co-existing within 'empirical incongruences' (2005: 453). This example is further testament to the process of hybridisation within the French model, a more modest, but a more defensible claim than assertions of convergence.

\section{Mechanism 3: The Market for Corporate Control}

Perhaps the most important mechanism by which the increased significance of capital markets for corporate funding is supposed in theory to change the behaviour and operations of firms is through the market for corporate control. Hitherto, the noyaux durs had been the crux of French 'protected capitalism', and the placing of controlling stakes in 'safe' hands provided an effective barrier to hostile takeovers. As noted above - these 
noyaux durs partially unravelled between 1995 and 2000. Some cite the BNP Paribas takeover in 2000 as evidence that a market for corporate control has emerged as a result (Cioffi 2000). If true, this marks a fundamental shift in French capitalism. Yet hostile takeovers remain comparatively rare in France. Only 3 hostile takeovers involving large firms $^{7}$ took place in France between 2000 and 2004 (Culpepper 2005, 193), and only 19 hostile takeovers took place between 1991 and 2000 (Montagne, Pernot \& Sauviat, 2002), illustrating that the French market for corporate control remains underdeveloped.

Thus, despite the demise of the noyaux durs, obstacles remain in the path of Anglo-Saxon market discipline. Some long-established characteristics of French corporate capitalism, including the enduring concentration of ownership and the internal constitutions of companies, continue to insulate management. One mechanism through which 'insiders' are empowered at the expense of 'outsiders' is differential shareholder voting rights. Much importance is attached to the 'one share, one vote, one dividend' principle within Anglo-Saxon influenced calls for 'good' corporate governance (OECD 1999; 2004). Once again we should note a disparity between the theory and practice of Anglo-Saxon capitalism. In reality, the US model in particular represents an 'impure' form of the Anglo-Saxon ideal type, with unequal voting rights a prevalent feature of its corporate governance arrangements (Monks \& Minow 2004: 122-126), part of management's hidden protectionist arsenal (Charkham 2005: 263-6, 276-286). Nevertheless, both UK and US institutional investors with significant stakes in French firms prioritise 'one share, one vote'. For all this, it has not become the French norm. A number of distinctive 
constitutional features designed to empower majority shareholders and marginalise minority shareholders highlight the enduring singularity of French corporate governance.

Double votes, although strictly regulated within French law, remain legal and attenuate accountability to market sentiment within large French companies. These can be used to 'lock up' the capital of a firm, and operate as an anti-takeover device, the 'poison pill' so disparaged by foreign institutional investors. As well as double votes, a range of voting ceilings limit the voting rights of certain investors. Both unequal voting rights and ownership ceilings are much more prevalent in France than in any other major economy (Goyer 2003a: 3). Furthermore, such practices are increasingly prevalent, suggesting their use as new instruments to limit foreign capital influence in French firms, replacing the noyaux durs (Magnier 2002: 73-4; Goyer 2003b 197 \& Table 6.5). Thus, in reaction the influx of foreign mutual and pension funds, large French firms are engaged in ‘defensive institutional engineering' (Markus 2005), using these mechanisms to resist the voice and influence of foreign capital within French capitalism. This is clearly a significant development in large French firms' organising of their corporate governance arrangements, of particular importance when interpreting the implications of the influx of Anglo-Saxon institutional investors.

In relation to takeovers, the NRE has introduced further financial transparency requirements upon potential takeover bidders (Journal Officiel 2001: 7776-7), requiring them, for example, to communicate with employees regarding their industrial strategy. There are also requirements for enhanced communication with the public, and other 
companies. Most significantly, the NRE does not eradicate any of the long standing impediments to takeovers noted above, therefore the NRE does not facilitate hostile takeovers. Thus this most important mechanism by which market discipline should in theory be brought to bear on firms and managers does not operate in the prescribed form in France (Hancké 2002: 26; O’Sullivan 2003: 25; Aglietta \& Rebérioux 2005: 70).

In addition to state actors' legislative interventions, French state actors have recently reengaged dramatically in the public debate surrounding hostile takeovers. In another example of quasi-dirigiste interventionism, as rumours spread of a possible hostile takeover of Danone by Pepsi in July 2005, the Interior and Finance Ministers vociferously opposed the move. Sarkozy said the government 'could not remain inactive when faced with a hostile takeover bid' for Danone. The public authorities had to 'do their utmost' and deploy all their 'powers of persuasion' to block the move. ${ }^{8}$ Notably they sought the Caisse des depots to deploy its considerable holdings, and exploit the poison pill clause within Danone's statutes which could prevent Pepsi taking control unless they could muster in excess of 66 per cent of the shares. The French state's open hostility to the planned bid may have been a key factor in scuppering the takeover, which never materialised. Similar dirigiste motives explained Finance Minister Thierry Bréton’s orchestration, in March 2006, of the merger of Gaz de France with Suez to protect the latter from a potential hostile takeover by the Italian energy giant Enel, ${ }^{9}$ and the French Government's vocal opposition to Mittal's planned hostile takeover of Arcelor in January $2006 .{ }^{10}$ 


\section{Conclusions}

At a glance from the global level, the changes in French financial market operations and regulation suggest evidence of convergence towards an Anglo-Saxon liberal market economy. However, when attention is focused on the mechanisms of change within models of capitalism, as here, the need to admit the notion of diversity in the explanation and characterisation asserts itself forcefully in seeking to understand how capitalism works in particular settings.

The central contention of this article is that the reason why the global convergence thesis misrepresents contemporary evolutions can be sought in insufficient attention being paid to mechanisms of change within models of capitalism. Secondly, this analysis has demonstrated how a 'recombinant capitalism' approach (Crouch 2005), framing its analysis in terms of hybridisation and fragmentation of national models, offers greater explanatory purchase over the French model, does less violence to the facts, and as such offers a promising way out of the 'convergence or persistence’ impasse.

Analysis of the mechanisms by which a transformed international political economic context might bring about changes within French capitalism has highlighted the problems of equating an influx of Anglo-Saxon institutional investors with a convergence of French corporate governance upon ‘Anglo-Saxon’ shareholder value norms. Foreign institutional investors are indeed a key motor for change within French capitalism, but 
that change is best understood as hybridisation, and 'recombination' of elements drawn from different models of capitalism.

The differential success of the institutions of shareholder value capitalism across different areas highlights the uneven distribution of new corporate governance institutions and practices within French capitalism. There are clear areas of Anglo-Saxon influence, notably in the area of financial market regulation. Yet the formal institutional change achieved has not transformed firm practices, with emergent transparency norms only partially inculcated into French capitalism. In relation to a number of extremely important potential mechanisms, there are enduring specificities that present major impediments to the 'shareholder value' paradigm, and its influence within French capitalism. Reactive mechanisms (double shares, voting ceilings) have been introduced, and these have erected new obstacles to a market for corporate control already hindered in the French context by the concentration of ownership.

This analysis of the import of shareholder empowering institutions into French capitalism also has implications for our understanding of institutional complementarity, one of the key notions within the Varieties of Capitalism paradigm (Hall \& Soskice 2001: 17-21). Here, institutional complementarity has been deployed not to explain persistence, but to show how the impact of a single institution in a given framework is mediated by the presence of other institutions, thus the same institution will produce different consequences across different institutional frameworks. The shareholder-oriented reforms were introduced in piecemeal fashion in France, yet their combination with and 
interaction with domestic institutions such as the intérêt social of the company produces different consequences than pro-shareholder mechanisms combined with principles of shareholder value, as in the UK. Thus similar institutional changes can produce different outcomes because change is located in a different (evolving and dynamic) set of institutional complementarities.

In this way, institutional complementarities channel change in particular directions, generating the diversity. Hybridisation, and recombination of capitalist institutions drawn from different models, provides a more convincing narrative than convergence to account for the changes outlined above. In a broader context, this highlights the importance of analysing the interaction of domestic and international factors in the political economy of capitalist restructuring. It further highlights the importance of carefully specifying the mechanisms of change when assessing the impact of international political economic change upon national models of capitalism. Factoring domestic mechanisms of change into the transnational approach represents a challenging but promising avenue of inquiry for understanding the political economy of global capitalism, combining the insights of comparative political economy and IPE analysis.

\footnotetext{
${ }^{2}$ In 2002, networks of influence constructed around three big banks - BNP, Société Générale and Crédit Lyonnais remained in place, and thirty directors enjoyed between them 160 seats on the boards of major French firms (Orange 2002).

${ }^{3}$ In February 2000, the investment funds NR Atticus and Wyser-Pratte \& Co. sought to sanction the management and change the composition of the board through their voting rights (32 per cent and 9 per cent respectively). Management sought to sell controlling shares to an ally, in order to reduce the funds' influence. The funds accused management of trying to protect their position against the intérêt social of the firm. The judges deemed they could not be certain that
} 
management actions were against the intérêt social of the company, and found in favour of the management (Magnier 2002: 70-71).

${ }^{4}$ Clift 2004: 340-342; Schmidt 2003: 539-40; Loriaux 2003: 113-4 \& 117-8; Hancké 2002: 62-5

5 'les pouvoirs les plus étendus'

${ }^{6}$ Significantly, the NRE brought transparency requirements to bear on non-quoted, as well as quoted companies. Non-quoted companies had hitherto been largely shielded from the transformations noted earlier in this article, and are often characterised as 'opaque' and 'monolithic'. Even in the wake of this change, there remains a gulf between quoted and nonquoted companies (Frison-Roche 2002: 79, 82-90), which remain - transparency requirements aside - outside the new regulatory requirements.

${ }^{7}$ where the deal was worth $\$ 100$ million or more

8 'Sarkozy et Danone : ni passivité ni nationalisation rampante’, Le Monde 22072005

9 'Suez-GDF-Enel : le choc des patriotismes, le poids des réseaux', Le Monde 05032006.

10 Le patriotisme, Arcelor et les PME’, Le Monde 05022006 


\section{Bibliography}

Alcouffe, C. (2000) 'Judges and CEOs: French Aspects of Corporate Governance’ European Journal of Law and Economics, 9 (2), pp. 127-44.

Aglietta M. and Rebérioux, A (2005) Corporate Governance Adrift? Cheltenham: Elgar Boutillier M., Labye A., Lagoutte C., Levy N., and Oheix V. (2002) ‘Financement et gouvernement des entreprises: exceptions et convergences européennes', Revue D’Economie Politique, № 4 (juillet-août), pp. 499-544 Campbell, J. (2004) Institutional change and Globalizion Princeton, NJ: Princeton University Press

Castells, M. ( 2000) The Rise of the Network Society Oxford: Blackwell.

Cerny, P. (1989) ‘The 'Little Big Bang’ in Paris: financial deregulation in a dirigiste system’, European Journal of Political Research, 17, pp. 169-192.

Charkham, J. with Ploix, H. (2005) Keeping Better Company Oxford: Oxford University Press.

Cioffi, J (2000) 'Governing Globalization? The State, Law, and Structural Change in Corporate Governance', Journal of Law and Society, 27 (4), pp. 572-600.

Clift, B. (2004) 'Debating the Restructuring of French Capitalism and Anglo-Saxon Institutional Investors: Trojan Horses of Sleeping Partners?', French Politics, 2 (3), pp. 333-346.

Clift, B. (2001) ‘The Jospin Way’, Political Quarterly, 72 (2), pp. 171-179 
Coffee, J. (1999)'The Future as History: The Prospects for Global Corporate Convergence in Corporate Governance and its Implications’ North-western University Law Review, 99, pp. 641-707.

Commissariat du Plan (2004) Mondialisation et recomposition du capital des enterprises européennes: rapport du groupe preside par Michel Dietsch (Paris: La documentation française).

Crouch, C. (2005) 'Models of Capitalism’, New Political Economy, 10 (4), pp. 439-456.

Culpepper, P. (2004). 'Capitalism, Coordination, and Economic Change: the French Political Economy since 1985' viewed at http://ksghome.harvard.edu/ .pculpepper.academic.ksg/changes\%20in\%20French\%20po litical\%20economy,\%20v2.pdf

Culpepper, P. (2005) 'Institutional Change in Contemporary Capitalism: Coordinated Financial Systems since 1990', World Politics, 57 (2), pp. 173 - 199

Desportes, G \& Mauduit, L (1999) La gauche imaginaire et le nouveau capitalisme, (Paris: Grasset).

EIRO (2001)

Forrester, V. (2000) L’horreur économique Paris: Livre de Poche.

Frison-Roche, M.-A. (2002) 'Le droit français des socétés entre corporate governance et culture de marché' in D. Plihon and J.-P. Ponssard (eds.) La montée en puissance des fonds d'investissement Paris: La documentation française, pp. 77-92.

Gilson, J. (2004) ‘Globalizing Corporate governance: convergence of form or function’ in J. Gilson \& M. Roe (eds.), Convergence and Persistence in Corporate Governance Cambridge: Cambridge University Press, pp. 128-160. 
Goyer, M. (2003a) ‘The Transformation of Corporate Governance in France’ Brookings Institution, US-France analysis Series.

Goyer, M. (2003b) 'Corporate Governance, Employees, and the Focus on Core Competencies in France and Germany’ in C. Milhaupt (ed.), Global Markets, domestic Institutions, Columbia University Pres: New York, pp. 183-213.

Goyer, M. \& Hancké, B. (2005) ‘Labour in French Corporate Governance: The Missing Link' in H. Gospel \& A. Pendleton (eds.), Corporate Governance and Labour Management Oxford: Oxford University Press, pp. 173-196

Hall, P. \& Soskice, D. (2001) ‘An Introduction to Varieties of Capitalism’ in P. Hall \& D. Soskice (eds.), Varieties of Capitalism Oxford: Oxford University Press, pp. 1-70.

Hancké. B. (2002) Large Firms and Institutional Change Oxford: Oxford University Press.

Hay, C. (2004) 'Common Trajectories, variable paces, divergent outcomes? Models of European Capitalism under conditions of complex economic interdependence', Review of International Political Economy, 11 (2), pp. 231-62.

Jackson, G. Hoepner, M. \& Kurdelbusch, A. (2005) 'Corporate Governance and Employees in Germany: Changing Linkages, Complementarities, and Tensions' in H. Gospel \& A. Pendleton (eds.), Corporate Governance and Labour Management Oxford: Oxford University Press, pp. 84-121 Jeffers, E. \& Magnier, V. 2002 'Le gouvernement des enterprises et les FIE au niveau international' in Plihon \& Ponssard (eds.) La montée en puissance des fonds d'investissement (Paris: La documentation Française), pp. 55-66. 
Journal Officiel (2001) 'Loi organique no. 2001-420 du mai 152001 relative aux nouvelles regulations économiques’, Journal Officiel de la République Française, 16 May, pp. 7776-7806.

Jospin, L. (1999) speech to the Journée parlementaire du groupe socialiste, Strasbourg, 27 September 1999, http://www.psinfo.net/

Kechidi, M. (2003) 'Fusions et Acquisitions: la financiarisation des logiques de concentration’ Working Paper, LEREPS, Université de Toulouse.

La Porta, R., Lopez-de-Silanes, F., Schleifer, A. and Vishny, R. (1998) ‘Law and Finance’ Journal of Political Economy, 106, pp. 1113-1155.

Lauer, S. (2002) ‘Malgré la mondialisation, le capitalisme familial se porte bien’ Le Monde 30 July.

Lemaitre, F. (2003) 'La France, championne du capitalisme familial’ Le Monde 18 April.

Levy, J. (ed.) (2006) The State After Statism Boston: Harvard University Press.

Loriaux, M. (1991) France After Hegemony Ithaca: Cornell University Press.

Loriaux, M. (2003) 'France: a new 'capitalism of voice’?’ in L. Weiss (ed.) States in the Global Economy Cambridge: Cambridge University Press, pp. 101-120.

Lütz, S. (2004) ‘Convergence Within National Diversity: The Regulatory State in Finance', Journal of Public Policy, 24 (2), pp. 169-197.

Macaire, S. and Rehfeldt, U. (2001) 'The Industrial Relations Consequences of Mergers:

France', European Industrial Relations Observatory Online, http://www.eiro.eurofound.eu.int/2001/02/word/fr0009188s.doc MacLean, M. (2002) Economic Management and French Business Basingstoke: Palgrave. 
Magnier, V. (2002) 'L'évolution du gouvernement d'entreprise en France’ in D. Plihon and J.-P. Ponssard (eds.) La montée en puissance des fonds d'investissement Paris: La documentation française, pp. 67-76.

Markus, S. (2005) 'Defensive Institutional Engineering and Global Convergence:

Corporate Governance Reforms in Russia’, Paper presented at the ECPR Conference, Budapest September 8-10.

McGrew, A. (2005) ‘The logics of globalization’ in J. Ravenhill (ed.) Global Political Economy Oxford: Oxford University Press, pp. 207-235.

Michalet, C.-A. (1997) 'France’ in J. Dunning (ed.) Governments, Globalization and International Business Oxford: Oxford University Press, pp. 313-334.

Milner, S. (1995) France in S. Berger \& D. Broughton (eds.) The Force of Labour: The West European Labour Movement and the Working Class in the Twentieth Century Oxford; Berg, pp. 211-244

Monks, R. \& Minow, N. (2004) Corporate Governance Oxford: Blackwell.

Montagne, S. Pernot, J.-M. \& Sauviat, C. (2002) 'Corporate governance systems and the nature of industrial restructuring: France’ European Industrial Relations Observatory Online, http://www.eiro.eurofound.eu.int/2002/09/word/fr0207107s.doc

Morin, F. (1998) Le modèle française de détention et de gestion du capital: analyse, prospective et comparaisons internationales’ Paris: Editions de Bercy Morin, F. (2000) 'A Transformation in the French Model of Shareholding and Management', Economy and Society, 29 (1), pp. 36-53.

Mottis, N. and Ponssard, J.-P. (2002) 'L'impact des FIE sur le pilotage de l'entreprise' 
in D. Plihon and J.-P. Ponssard (eds.) La montée en puissance des fonds d'investissement Paris: La documentation française, pp. 125-146.

O’ Sullivan, M. (2003) 'The political economy of comparative corporate governance' Review of International Political Economy, 10 (1), pp. 23-72.

OECD (1999) Principes relatifs au gouvernement d'entreprise. Paris: OECD OECD (2004) OECD Principles of Corporate Governance: 2004 Paris: OECD

Orange, M. (2002) 'Ce petit cercle d’administrateurs qui se partage les responsabilités en France' Le Monde 19 July.

Perraton, J. \& Clift, B. (2004) 'So Where are National capitalisms Now?', in Perraton \& Clift, (eds.), 'Where Are National Capitalisms Now?’ Basingstoke: Palgrave. pp. 195261.

Polanyi, K. (2001[1944]) The Great Transformation Boston: Beacon Press.

Plihon, D. (2003) 'Les mutations du capitalisme en France: le role de la finance’ Les notes de l'ifri, 50 Paris: Ifri, pp. 1-71.

Plihon, D. Ponssard, J.-P., Zarlowski, P. (2002) 'Conclusion: Quel scenario pour le gouvernement d'entreprise? Un hypothèse de double convergence' in D. Plihon and J.-P. Ponssard (eds.) La montée en puissance des fonds d'investissement Paris: La documentation française, pp. 163-174.

Schmidt, V. (1996) From State to Market? The Transformation of French Business and Government. Cambridge: Cambridge University Press.

Schmidt, V. (2003). 'French capitalism transformed, yet still a third variety of capitalism’ Economy and Society, 32 (4), pp. 526-554. 
Tiberghien, Y. (2004) 'Global Forces, Political Mediation, and the Fragmentation of Corporate Governance Patterns: The Cases of France, Japan and Korea’, Paper Presented at the APSA Conference, Chicago.

UNCTAD 2003. World Investment Report 2003: Country Fact Sheet: France Viénot, M. (1995) 'Rapport sur le conseil d'administration des sociétés cotées’ Revue de Droit des Affaires Internationales, 8, pp. 933-945.

Viénot, M. (1999) (preside par) ‘Rapport sur le conseil d’administration des sociétés cotées’ AFEP and MEDEF. Vogel, S. (1996) Freer Markets, More Rules? Ithaca: Cornell University Press. 